\title{
Study on Particulate Matter of Diesel Engine Using Waste Cooking Oil
}

\section{Nur Fauziah Jaharudin ${ }^{1, a}$, Nor Atiqah Ramlan ${ }^{1, b}$, Mohd Herzwan Hamzah ${ }^{1, c}$, Abdul Adam Abdullah ${ }^{1, d}$, Rizalman Mamat ${ }^{1, e}$}

\author{
${ }^{1}$ Faculty of Mechanical Engineering, University Malaysia Pahang, Pahang, Malaysia \\ afauziahjs@gmail.com, batiqahramlan3@gmail.com, cherzwan@gmail.com,

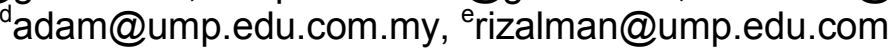

Keywords: Particulate matter, soluble organic fraction, soot, waste cooking oil, biodiesel

\begin{abstract}
Particulate matter (PM) is one of the major pollutants emitted by diesel engine which have adverse effects on human health. Accordingly, many researches have been done to find alternative fuels that are clean and efficient. Biodiesel is preferred as an alternative source for diesel engine which produces lower PM than diesel fuel. However, the manufacturing cost of biodiesel from vegetable oil is expensive. Therefore, using waste cooking oil (WCO) for biodiesel would be more economical and sustainable solution. The characteristics of direct injection diesel engine in term of the PM have been investigated experimentally in this study. The experiments were conducted using single cylinder diesel engine with different speed $(1200 \mathrm{rpm}, 1500 \mathrm{rpm}, 1800 \mathrm{rpm}$, $2100 \mathrm{rpm}, 2400 \mathrm{rpm}$ ) at constant load. PM emission of WCO B100 and diesel fuel was compared and the effect of PM components such as soluble organic fraction (SOF) and soot were studied. The result showed WCO B100 reduces the PM emission at all engine speed. Furthermore, both fuels showed highest reduction of PM concentration at moderate engine speed of $1500 \mathrm{rpm}$.
\end{abstract}

\section{Introduction}

With the increasing price and depletion source of crude oil, interest in biodiesel is growing remarkably. Biodiesel is one of the better sources for diesel engine. It offer several advantages compare to petroleum oil which provides lower hydrocarbon (HC) and carbon monoxide (CO) emissions, higher cetane number, less smoke and particulate matter (PM). However, a major difficult in commercializing biodiesel from vegetable oil is its high manufacturing cost. Research showed that $70-95 \%$ of the total biodiesel production cost is for production of virgin vegetable oils due to huge fertile land needed for crops [1-3]. WCO is the promising alternatives for biodiesel due to the less expensive prices compared to other feedstock such as food-grade canola and soybean oil [4]. Therefore, biodiesel from WCO is one of the better ways to utilize it efficiently and economically.

The developments of diesel engines are widely used in automotive industries due to high thermal efficiency and high durable performance than gasoline engine [5-8]. On the other hand, diesel engines exhaust emission produce substance that contribute to environment pollution and health effect like carbon monoxide, unburned $\mathrm{HC}, \mathrm{PM}$ and nitrogen oxide $\left(\mathrm{NO}_{\mathrm{x}}\right)$ [9, 10]. Therefore, decreasing the level of exhaust gas emissions is always regarded as an important aim to be achieved in diesel engine research. Studies indicate that particulate matter can penetrate the cell membranes, enter the blood and even reach the brain [11]. Many researchers reported that the main factor affecting PM emission is the fuel oxygen content [12]. These experiments were conducted to study the effects of WCO B100 towards the diesel engine in term of particulate matter emissions.

\section{Research Methodology.}

The experimental work was conducted on single cylinder direct injection combustion, YANMAR TF120 diesel engine. Figure 1 shows the schematic diagram of the test engine used in this study. A positive displacement gear pump model Hydrome model HGP-3A-F23 as dynamometer to apply 
load to the engine. In this study, the load was set to be constant at 800 psi for each speed. The exhaust gas was sampled at $50 \mathrm{~cm}$ downstream of the exhaust extractor. In this study, biodiesel and diesel fuel were prepared for the engine testing. Biodiesel was originated from WCO and has been transesterified into biodiesel. The process followed ASTM D6751 guidelines and the biodiesel fuel met the standard specification. Table 1 summarizes the detail properties of the test fuels.

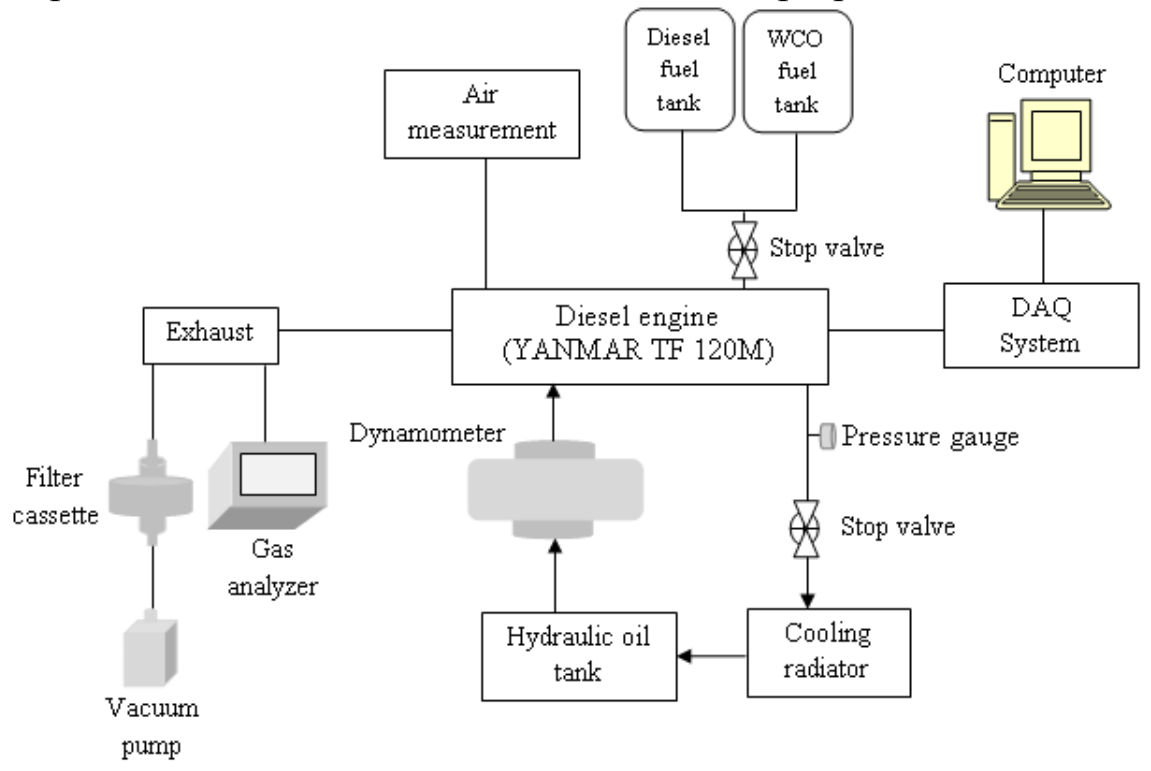

Figure1: Schematic diagram of engine test rig and exhaust emission sampling

Table 1: Fuel Specification

\begin{tabular}{|c|c|c|c|}
\hline Parameter & $\begin{array}{l}\text { ASTM } \\
\text { D6751 }\end{array}$ & Diesel & $\begin{array}{l}\text { WCO } \\
\text { B100 }\end{array}$ \\
\hline $\begin{array}{ll}\text { Density } & \left(\mathrm{g} / \mathrm{cm}^{3}\right) \\
\end{array}$ & 0.88 & 0.843 & 0.882 \\
\hline Acid Number $\quad(\mathrm{mgKOH} / \mathrm{g})$ & $0.5 \max$ & 0.270 & 0.340 \\
\hline Cetane Number & $>46$ & 46.6 & 57.7 \\
\hline $\begin{array}{ll}\text { Calorific Value } & (\mathrm{MJ} / \mathrm{kg})\end{array}$ & $\mathrm{N} / \mathrm{A}$ & 42.32 & 35.02 \\
\hline $\begin{array}{l}\text { Kinematic Viscosity } \\
\text { at } 40^{\circ} \mathrm{C} \quad\left(\mathrm{mm}^{2} / \mathrm{s}\right)\end{array}$ & $1.9-6.0$ & 3.718 & 4.282 \\
\hline $\begin{array}{ll}\text { Cloud Point } & \left({ }^{\circ} \mathrm{C}\right)\end{array}$ & $\mathrm{N} / \mathrm{A}$ & -3 & 8 \\
\hline Pour Point & N/A & -10 & -4 \\
\hline
\end{tabular}

The engine was run with diesel fuel until it reaches steady state condition. The exhaust emissions tests were conducted at engine speed with range of $1200 \mathrm{rpm}, 1500 \mathrm{rpm}, 1800 \mathrm{rpm}, 2100$ $\mathrm{rpm}$ and $2400 \mathrm{rpm}$. The particulate emission was trapped on the $47 \mathrm{~mm}^{2}$ size diameter composite filter paper (PTFE coated). The total mass concentration was measured by a Sartorius high precision electric balance. The filters were weighted under controlled temperature and relative humidity. Oven was used to heat the filter before and after the experiment in order to avoid the humidity on the filter during the filter was weighted. The duration and temperature of heating process is controlled within two hours at $50{ }^{\circ} \mathrm{C}$. SOF and soot can be extracted by soaking the filter with dichloromethane solution for 24 hours. PM, SOF and soot concentration be calculated as mentioned below:

a) Particulate Matter (PM)

$$
\begin{array}{ll}
\text { Mass of filter (before) } & =\mathbf{a}(\mathrm{g}) \\
\text { Mass of filter (after) } & =\mathbf{b}(\mathrm{g}) \\
\mathrm{PM}(\mathbf{c}) & =\mathrm{b}-\mathrm{a}(\mathrm{g})
\end{array}
$$




$$
\mathrm{PM}(\mathrm{c} / 20 \mathrm{~L}) * 1000 \quad=\mathbf{d}\left(\mathrm{g} / \mathrm{m}^{3}\right)
$$

b) Soluble Organic Fraction (SOF)

$$
\begin{array}{ll}
\text { Dichloromethane solution } & =\mathbf{e}(\mathrm{g}) \\
\operatorname{SOF}(\mathbf{f}) & =\mathrm{b}-\mathrm{e}(\mathrm{g}) \\
\operatorname{SOF}(\mathrm{f} / 20 \mathrm{~L}) * 1000 & =\mathbf{g}\left(\mathrm{g} / \mathrm{cm}^{3}\right)
\end{array}
$$

c) Soot

$$
\text { Soot }(\mathbf{h}) \quad=\mathrm{d}-\mathrm{g}\left(\mathrm{g} / \mathrm{cm}^{3}\right)
$$

\section{Results and Discussion.}

a) PM Concentration. Fig. 2 shows the variation of PM concentration against engine speed fuelled with WCO B100 and diesel fuel. This result indicates that PM emissions were influenced by engine speed. Based on Fig. 2, WCO B100 gives lower PM concentration compared to diesel fuel. The PM reduction of WCO B100 was showed in Fig. 3. The percentage reductions of PM emission were decreased from $1200 \mathrm{rpm}$ to $1500 \mathrm{rpm}$ which is at lower engine speed and increased for higher engine speed. In this case, the highest reduction of PM emission occurred when the engine speed is at $2400 \mathrm{rpm}$ which is $21.82 \%$ of reduction and the lowest reduction is at $1800 \mathrm{rpm}$ which is $5.56 \%$. $\mathrm{PM}$ reduction at $1200 \mathrm{rpm}, 1500 \mathrm{rpm}$ and $2100 \mathrm{rpm}$ is $19.05 \%, 13.33 \%$ and $10.71 \%$ respectively. PM were mainly formed in the locally fuel rich region in the combustion chamber, Due to high temperature and available oxygen, PM were burns at the boundary of diffusive flame. When the engine speed is increase, the particulates are combust with lack of oxidation time. Therefore, PM emission increase with the increasing engine speed [13].

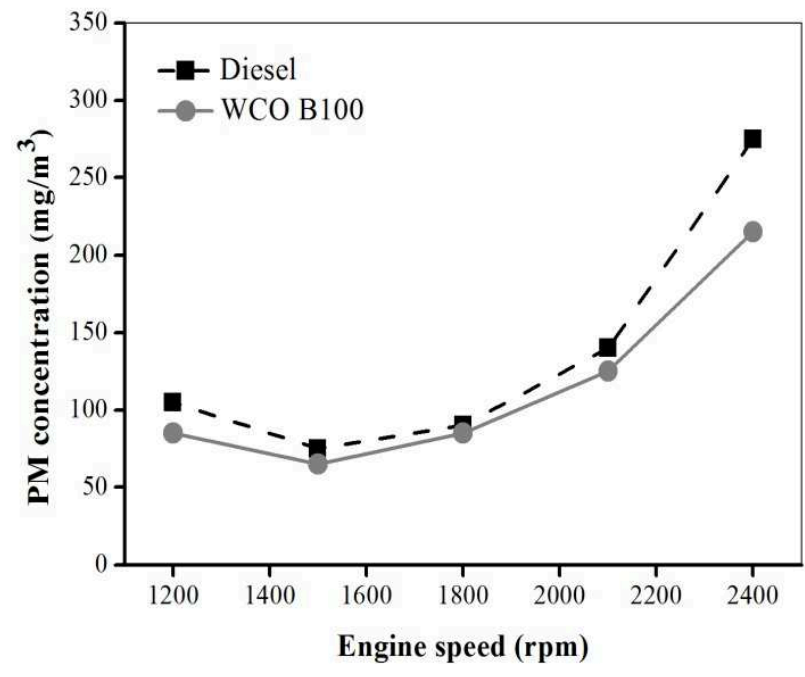

Figure 2: PM Concentration

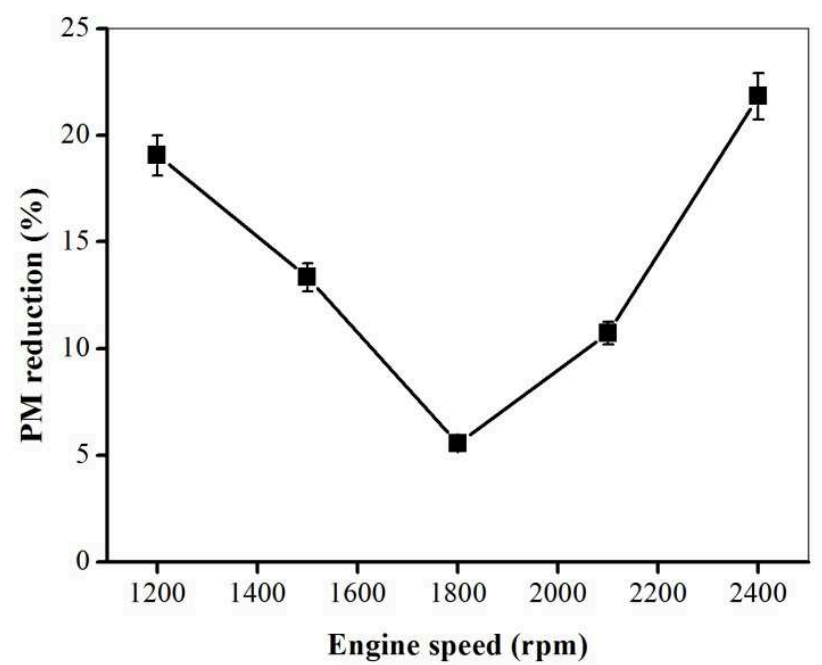

Figure 3: PM reduction of WCO B100

Many authors contributed the reduction in PM emission due to higher oxygen content in biodiesel. Frijters and Baert found a good correlation between PM emission and fuel oxygen content with various biodiesel fuels [14]. Lower oxygen content fuel will produce high level PM due to unburned hydrocarbon (HC) emissions. These $\mathrm{HC}$ will condense and absorbed on the PM surface resulting an increase of PM emissions. Thus, the oxygen content in the biodiesel fuel, allow more complete and further promote the oxidation of soot in order to reduce the PM emissions.

b) SOF component. Fig. 4 shows the comparison of SOF concentration contain in the PM between WCO B100 and diesel. The figure showed the SOF concentration of WCO B100 is higher than diesel fuel for all engine speed which is $52.38 \%, 20 \%, 27.78 \%, 32.14 \%$ and $56.36 \%$ at engine 
speed $1200 \mathrm{rpm}, 1500 \mathrm{rpm}, 1800 \mathrm{rpm}, 2100 \mathrm{rpm}$ and $2400 \mathrm{rpm}$ respectively. While the percentage of SOF component from its total PM mass for WCO B100 is $64.70 \%, 84.62 \%, 47.06,72 \%$ and $79.07 \%$ at engine speed $1200 \mathrm{rpm}, 1500 \mathrm{rpm}, 1800 \mathrm{rpm}, 2100 \mathrm{rpm}$, and $2400 \mathrm{rpm}$ respectively. The SOF concentration is higher for WCO B100 in consequence of its lower energy content compared to diesel fuel which leads to incomplete combustion of HC. Thus, causing the increment of SOF component [15].

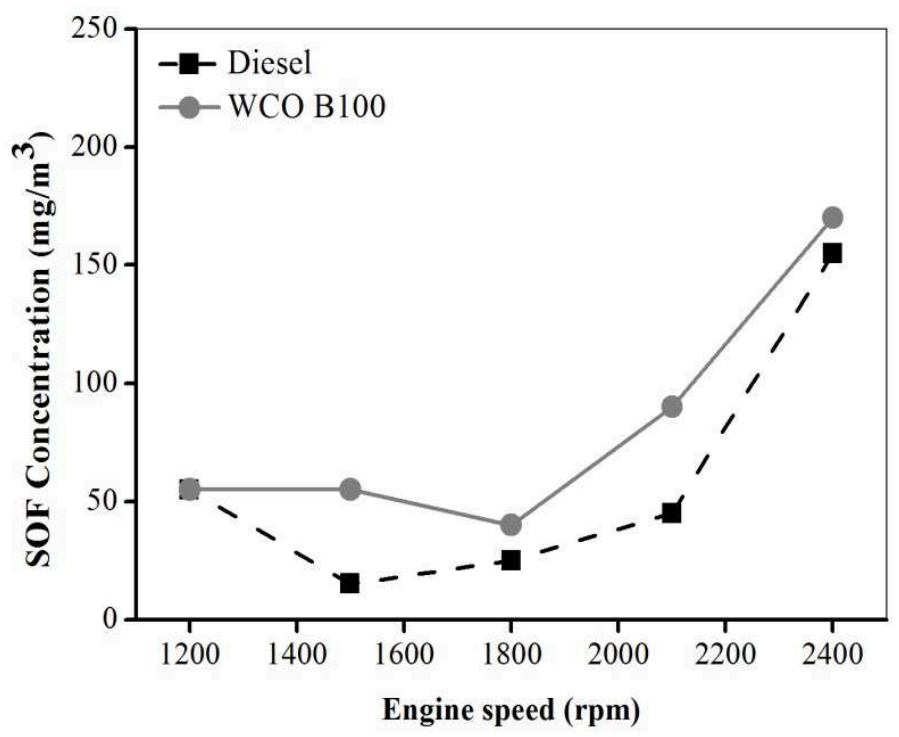

Figure 4: SOF concentration

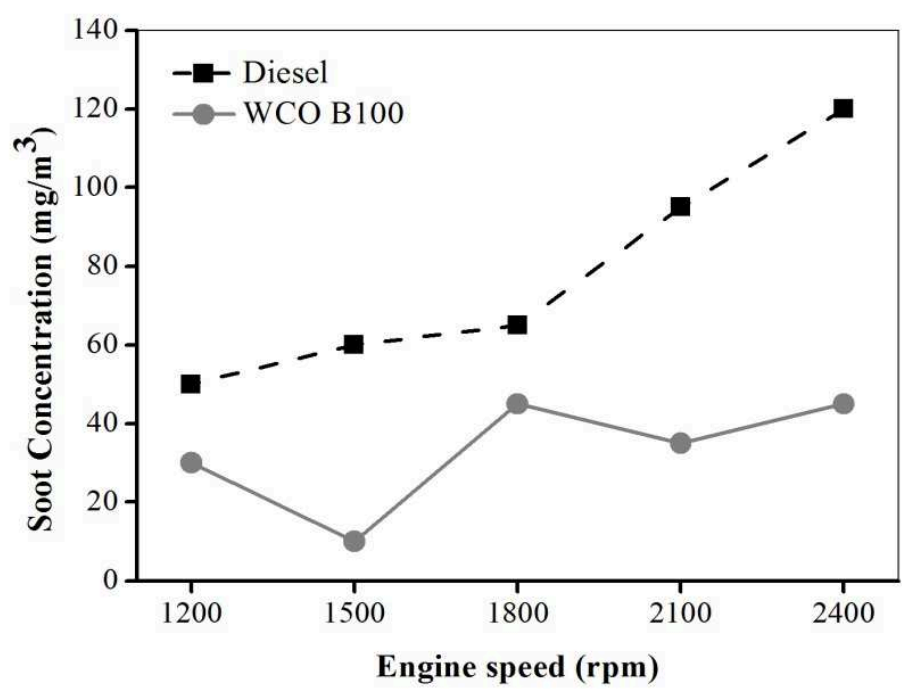

Figure 5: Soot concentration

c) Soot component. Fig. 5 shows soot concentration obtained from WCO B100 and diesel fuel. The graph shows that diesel fuel has higher soot concentration compared to WCO B100. The percentage of soot component from its total PM mass for diesel is $47.62 \%, 80 \%, 72.22 \%, 67.86 \%$ and $43.64 \%$ at engine speed $1200 \mathrm{rpm}, 1500 \mathrm{rpm}, 1800 \mathrm{rpm}, 2100 \mathrm{rpm}$ and $2400 \mathrm{rpm}$ respectively. Otherwise, the percentage of soot component for WCO B100 at engine speed $1200 \mathrm{rpm}, 1500 \mathrm{rpm}$, $1800 \mathrm{rpm}, 2100 \mathrm{rpm}$ and $2400 \mathrm{rpm}$ is $35.29 \%, 15.38 \%, 52.94 \%, 28 \%$ and $20.93 \%$ respectively. It is seen that soot has dominant role in the PM formation by using diesel fuel. Thus, it is revealed that WCO B100 has a capability to reduce the soot effectively compared to diesel fuel. 


\section{Conclusion}

The PM emission of WCO and diesel fuel were investigated in this study. The results indicated that WCO B100 showed reduction of PM emission for every engine speed due to its high oxygen content. The SOF concentration for WCO B100 also higher than diesel at each engine speed where the unburned or partially burned HC condensed and absorbed on PM surface. Otherwise, diesel fuel showed higher soot concentration in comparison with WCO B100. From this study, it can be seen that both components play an important role in PM formation. Due to its lower energy content, PM formation of WCO B100 is mainly composed of SOF component compared with diesel fuel which mainly composed of soot. In addition, both fuels showed highest reduction of PM concentration at moderate engine speed of $1500 \mathrm{rpm}$. Thus, at $1500 \mathrm{rpm}$, it is the optimum speed in order to have a minimum PM.

\section{References}

[1] Dorado, M., et al., An approach to the economics of two vegetable oil-based biofuels in Spain, Renewable Energy. 31 (2006) 1231-1237.

[2] Marchetti, J., V. Miguel, and A. Errazu, Techno-economic study of different alternatives for biodiesel production, Fuel Processing Technology. 89 (2008) 740-748.

[3] Khan, T.M.Y., et al., Recent scenario and technologies to utilize non-edible oils for biodiesel production, Renewable and Sustainable Energy Reviews. 37 (2014) 840-851.

[4] Canakci, M. and J. Van Gerpen, A pilot plant to produce biodiesel from high free fatty acid feedstocks, Transactions of the ASAE. 46 (2003) 945-954.

[5] Abdullah, N.R., et al., Effect of Injection Pressure with Split Injection in a V6 Diesel Engine, SAE Technical Paper. (2009) 0049.

[6] Chen, H., S. Shi-Jin, and W. Jian-Xin, Study on combustion characteristics and PM emission of diesel engines using ester-ethanol-diesel blended fuels, Proceedings of the Combustion Institute. 31 (2007) 2981-2989.

[7] Graboski MS, M.R., Combustion of fat and vegetable oil derived fuels in diesel engines, Prog Energy Combust Sci 1997;24:125-64. (1997).

[8] Murillo S, M.J., Porteiro J, Granada E, Moran JC, Performance and exhaust emissions in the use of biodiesel in outboard diesel engines., Fuel 2007;86(12-13):1765-71. (2007).

[9] Gaffney, J.S. and N.A. Marley, The impacts of combustion emissions on air quality and climate (From coal to biofuels and beyond), Atmospheric Environment. 43 (2009) 23-36.

[10] Gangwar, J.N., T. Gupta, and A.K. Agarwal, Composition and comparative toxicity of particulate matter emitted from a diesel and biodiesel fuelled CRDI engine, Atmospheric Environment. 46 (2012) 472-481.

[11] Oberdörster, G., Sharp, Z., Atudorei,V., Elder, A., Gelein, R., Kreyling,W., \& Cox, C., Translocation of inhaled ultrafine particles to the brain, Inhalation Toxicology, 16, 437-445. (2004).

[12] Liotta, F.J. and D.M. Montalvo, The effect of oxygenated fuels on emission from a modern heavy-duty diesel engine, SAE TRANSACTIONS. 102 (1993) 1420-1420.

[13] Kim, M.Y., et al., Characteristics of particulate emissions of compression ignition engine fueled with biodiesel derived from soybean, Journal of Engineering for Gas Turbines and Power. 130 (2008) 052805.

[14] Frijters, P. and R. Baert, Oxygenated fuels for clean heavy-duty diesel engines, International journal of vehicle design. 41 (2006) 242-255.

[15] Armas, O., K. Yehliu, and A.L. Boehman, Effect of alternative fuels on exhaust emissions during diesel engine operation with matched combustion phasing, Fuel. 89 (2010) 438-456. 